Please cite this article as:

Teller, Christoph, Kotzab, Herbert, Grant, David. B. 2012. The Relevance of Shopper Logistics for Consumers of Store-based Retail Formats, Journal of Retailing and Consumer Services, 19 (1), 59-66, DOI: 10.1016/j.jretconser.2011.09.001. 
The Relevance of Shopper Logistics for Consumers of Store-based Retail Formats

Christoph Teller ${ }^{\text {I }}$, Herbert Kotzab ${ }^{\text {II }}$ and David B. Grant ${ }^{\text {III }}$

I, [corresponding author] The Surrey Business School, University of Surrey, GU2 7HX Guildford, United Kingdom; Tel: +44 (0)1483 682851, e-mail: c.teller@ surrey.ac.uk;

II, Institute for Logistics and Supply Chain Management, University of Bremen, 2000 Bremen, Germany; Tel.: +49 (0)421 218 66981, e-mail: kotzab@uni-bremen.de; CBS International Professor, Glasgow Caledonian University;

III, Logistics Institute, University of Hull, HU6 7RX Hull, United Kingdom; Tel.: +44 (0)1482 347500, e-mail d.grant@ hull.ac.uk; 


\title{
The Relevance of Shopper Logistics for Consumers of Store-based Retail Formats
}

\begin{abstract}
This paper discusses and empirically evaluates the relevance of shopping-related logistics for consumers of store-based retail formats. Based on a literature review a conceptual model was developed and subsequently tested using a survey of more than six hundred consumers in the grocery retail sector. Respondents were those primarily responsible for grocery shopping in their households located in a highly concentrated European urban retail market. Variance based structural equation modelling reveals that shopper logistics has a major impact on the convenience of store-based shopping and partly influence consumers' perceptions of shopping related costs. Nevertheless, shopper logistics does not affect consumer behaviour in terms of the share of visits of a store. These results are moderated by age, hedonic shopping orientation, shopping frequency, average spending per trip and store format preference. We conclude that shopper logistics is relevant for consumers of grocery stores but its relevance varies between different shopper groups.
\end{abstract}

Keywords: Shopper logistics, retail format, grocery sector 


\section{Shopper Logistics and Consumers of Store-based Retail Formats}

\section{Introduction}

Everyday across the globe consumers fulfil their grocery shopping needs in self-service, store-based retail formats such as convenience/discount stores, supermarkets or hypermarkets. Due to the self-service nature of these store formats consumers also fulfil instore to home logistics tasks, which we term shopper logistics, such as handling, picking, packing, transportation and storage at home (Granzin and Bahn, 1989). Retail stores can therefore be considered as demand fulfilment centres where consumers assemble their individual baskets of products or commodities (Alba et al., 1997).

However, consumers nowadays have more choice to use home delivery services that allow grocery retailers to fulfil certain logistics tasks using non-store-based retail formats (Murphy, 2003). Overall, there has been a steady rise in the market share of non-store retailing due to the growing use of the Internet as an information and order processing tool (Mintel, 2009); however the share of online sales remains less than $10 \%$ of total retail sales (KPMG, 2011). Further, different forms of non-store retailing cannibalise each other rather than taking away market share form store-based retail formats (Mintel, 2010). In the grocery sector - arguably the most important retail sector - the online market remains an even smaller niche. In the UK where online grocery retailing is already highly developed and widely accepted by consumers the share of online sales is about 5\% relative to the total grocery sales (Mintel, 2009; KPMG, 2011).

The dominance of store-based retailing indicates that consumers and most importantly shoppers still manage the flow of products and related information between the retail stores 
and their households, i.e. they execute shopper logistics on an everyday basis and to a considerable degree (Kotzab and Teller, 2005a).

And yet, in terms of shopper logistics the procurement of groceries is a necessity and cannot be easily deferred by consumers having no possibility to have it done by someone else (Teller and Gittenberger, 2011). The perishable nature of groceries results into a comparably high shopping frequency, which is determined by those products that are needed most and have the shortest storage life, e.g. diary products, fruits or vegetables (Kotzab and Teller, 2005b). Since most consumers have a lack of choice and have to shop for groceries at least once or perhaps several times a week, shopper logistics tasks and costs are higher compared to shopping endeavours for other product categories.

However, a key question that remains is why do consumers still prefer store-based retail formats for grocery shopping? Arguably this is an inconvenient, time consuming and cost creating task that is repeated frequently (Ingene, 1984). So far, the literature has dealt with the phenomenon of logistics-related tasks being carried out by consumers when they shop for groceries in a descriptive way. However, it has failed to investigate consumers' perceptions about the logistics process and consequently its relevance regarding patronage behaviour of store-based formats.

This paper's aim is to discuss and evaluate the relevance of shopping-related logistics tasks or shopper logistics to consumers of store-based retail formats in the grocery sector. The major contribution of this paper for retail and service research is to provide further insights into the perceived role of consumers as unwillingly and/or unconscious active members in the food supply chain. Thus, this paper contributes to a better understanding of the co-production of distribution services in store-based grocery retailing. 
This paper is organised as follows: after these introductory remarks we present a literature review that provides a synopsis of the dormant discussion on shopper logistics. Based on that, five hypotheses are developed within a conceptual model, then, the methodological characteristics for empirically testing this model and the results from this research are presented. In the discussion section the findings are reflected upon with respect to the existing literature. A research limitations and outlook section concludes the paper.

\section{Literature Review}

The role of a household is that of the last link in a supply chain, following the notion of 'point-of-origin to point-of-consumption' familiar in the logistics and supply chain management (SCM) discipline (CSCMP, 2011). However, the relevance of shopping-related logistics for consumers or shopper logistics has not received wide attention in the marketing, retailing or logistics literature. Notwithstanding, we have identified four research streams investigating the role of households in supply chains and consequently consumers acting as logisticians:

Consumer logistics: Granzin and Bahn (1989) provided the first explicit conceptual discussion of consumer logistics. They transferred the concept of business logistics to a logistics setting in households. They set up a process model that describes and categorises logistics tasks undertaken by consumers. Based on that, they then presented a research agenda to guide future research. Subsequent descriptive publications of Granzin and colleagues proposed consumer logistics tasks or logistics-related household characteristics as segmentation criteria of markets (Granzin et al., 1997, 2005). Overall, these publications included not only the logistics attached to shopping but also the logistics processes within households. However, their simple idea of looking at households as logistics systems has not 
yet been picked up by other authors to a substantial degree and there has been little empirical study.

Non-store retailing: With the appearance and growing use of the Internet authors have begun to enlarge on the topic of distance and non-store retailing and thus the 'insourcing' of shopper logistics tasks (e.g. Eastlick and Feinberg, 1999; Ring and Tigert, 2001; Ward, 2001; Gehrt and Yan, 2004; Hansen, 2008). This body of literature considers store-based shopping and related logistics tasks as an 'antithesis' of non-store retailing but does not provide in-depth discussions or empirical insights into the relevance of shopper logistics. These papers convey the tacit assumption in the way that shopping in store-based formats is an exhausting and/or annoying task for consumers - possibly because of shopper logistics. Thereby the authors focus more on the utilitarian rather than the hedonic dimension of shopping and orientation of consumers (Babin et al., 1994).

Recent non-store retailing literature has focused on the use of the Internet and its implications on consumer behaviour (Dennis et al., 2009; Hernandez et al., 2009). Regarding retailers, the literature has investigated their success strategies (Doherty and Ellis-Chadwick, 2009) and relationship with logistics service providers and consumer service quality (Xing and Grant, 2006; Xing et al., 2010). However, none have been concerned with consumer or shopper logistics activities.

Store-based retailing: The most consideration of selective shopper logistics tasks can be found in store (format) choice and patronage literature, although the notions of shopper and consumer logistics are only conveyed implicitly. Particular temporal and spatial aspects of shopping in terms of distance or accessibility have received considerable attention since seminal work from Reilly (1931) and Huff (1964), for example Fotheringham (1988), Grace 
and O'Cass (2005), Pan and Zinkhan (2006) and Reutterer and Teller (2009). Some other authors have focussed on convenience by providing infrastructural services (e.g. signage, recreational areas, specially adapted trolleys) or services facilitating the shopping process (e.g. information services, sales advice and self-service technologies) (Bearden, 1977; Reinartz and Kumar, 1999; Tang et al., 2001; Baker et al., 2002; Beatson et al., 2006). Overall though, the logistics contribution of consumers and its relevance is not discussed or investigated holistically.

Cost of shopping: Another research stream tries to convert shopping endeavours and therefore shopper logistics into tangible costs. Ingene (1984) conceptually discussed measures of labour productivity with respect to consumers' shopping endeavours and thereby considered measures of shopper logistics in terms of time, money and psychic efforts. Bell et al. (1998) extensively discussed the extent of shopping costs and tied them into a choice model to predict store patronage behaviour. Ruiz et al. (2004) included a quasi measure for (non-economic) costs in their activity-based segmentation approach with regards to shopping mall clientele. They used perceptual measures like accessibility and distance to operationalise shopping related costs. Lastly, Kotzab and Teller (2005a) provide empirical evidence that the estimated transportation costs related to shopping trips to (centrally located) supermarkets and (peripherally located) category killers play a significant but still marginal role in explaining the willingness to pay for home delivery services. However, the work around the topic of 'cost of shopping' has only considered shopper logistics to a marginal degree; the authors did though provide applicable notions to measure the relevance of shopper logistics for consumers.

After reviewing these different literature streams related to the shopper logistics phenomena, we consider there is a substantial gap in actually operationalising and measuring the 
relevance of logistics endeavours of store-based retail format consumers. The discussion of shopper logistics is not recent, quite scattered, implicit, and unfocused, which results in the broad set of contributions illustrated above. Further, there is a deficit of empirical studies regarding the extent of logistics tasks undertaken by consumers when they shop. We propose a conceptual model in the next section to address these shortcomings in line with empirical research aims provided in the introduction.

\section{Conceptual model}

Unlike Granzin's work which includes logistics processes within households we focus on the logistics activities during the shopping process. Shopper logistics includes a range of different activities such as transportation, picking and packing and is heavily influenced by how a retailer operates a certain store format strategy. These retail factors in particular comprise:

- the location that determines the distance to and the accessibility of stores,

- the store layout and space management that influences the manoeuvrability of shoppers and internal accessibility of products in store, and

- the provision of infrastructure services (e.g. signage, support by sales staff, sufficient cash desks, facilitating the orientation within the store).

How shoppers interpret and perceive these stimuli (i.e. the use of marketing instruments or format) affect their attitudes and behaviour according to stimulus-organism-response (S-O-R) theory - and consequently explain the relevance of shopper logistics for consumers of storebased retail formats. The S-O-R framework (Donovan and Rossiter, 1982) is rooted in the work of Mehrabian and Russell (1974) whereby a stimulus is posited to lead to an evaluation and emotional reaction which subsequently influences consumer behaviour. This model has 
been successfully applied in the retail environment (e.g. Mazursky and Jacoby, 1986; Finn and Lourviere, 1996; Sherman et al., 1997).

Our conceptual model is therefore derived from the S-O-R framework within which we identify our hypotheses. It proposes relationships between retail format strategy (stimuli like location, merchandising, store layout, pricing, and promotion), consumers' perceptions of the resulting shopper logistics and consumers' evaluations of store-based shopping (organism) that result into patronage intentions and behaviour (response). Further we focus on the organism part and investigate how shoppers process the stimuli and convert them into meaningful information (perception of shopper logistics) which is used to evaluate the environment (store-based shopping) and results into a reaction in terms of behaviour (Finn and Lourviere, 1996). Thus the significance and strength of the relationships or effects between constructs measuring shopper logistics and the reference constructs (i.e. overall evaluation of store-based shopping and patronage behaviour) serve as indicators for the relevance of shopper logistics. We now turn to the development of the conceptual model and our constructs.

Shopper logistics is perceived by various attributes of store-based shopping process from a consumer's point of view (Granzin et al., 2005). This comprises attributes related to transportation (i.e. easy access $\left(x_{11}\right)$ ), picking (i.e. clear store layout $\left(x_{12}\right)$, good arrangement of products $\left(x_{13}\right)$, clear display of prices $\left(x_{14}\right)$ and support of the sales personnel $\left.\left(x_{15}\right)\right)$, payment and packing (i.e. sufficient checkouts $\left(x_{16}\right)$ ). Further, shopper logistics is perceived as the time invested in the whole process, which comprises the time spent to access and return from the store $\left(x_{21}\right)$ and the time spent in the store $\left(x_{22}\right)$ (Ingene, 1984; Gert and Yan, 
2004). In summary, we propose store-related shopper logistics attributes $\left(\xi_{1}\right)$ and the time spent on store-based shopping $\left(\xi_{2}\right)$ as measures for shopper logistics.

Granzin et al. (2005) consider shopper logistics has a substantial effect on a consumer's perceived convenience of store-based shopping. According to Eastlick and Feinberg (1999) the convenience of shopping $\left(\xi_{3}\right)$ can be measured by overall convenience $\left(x_{31}\right)$, the amount of physical effort $\left(x_{32}\right)$, time intensiveness $\left(x_{33}\right)$ and the level of 'hecticness' $\left(x_{34}\right)$ attached to the whole process. We therefore propose the following two hypotheses:

$\mathrm{H}_{1 \mathrm{a}}$ : The better store-related shopper logistics attributes $\left(\xi_{1}\right)$ are perceived the better the convenience of store-based shopping $\left(\xi_{3}\right)$ is perceived.

$\mathrm{H}_{1 \mathrm{~b}}$ : The longer the shopper logistics-related time $\left(\xi_{2}\right)$ the worse the convenience of storebased shopping $\left(\xi_{3}\right)$ is perceived.

Another measure to evaluate store-based shopping and its burden on consumers is the cost attached to buying groceries from stores ( $\eta_{2}$; Bell et al., 1998; Kotzab and Teller, 2005a). This cost comprises both fixed and variable components for transportation, picking or packing and general opportunity costs ( $x_{41}$; Ingene, 1984; Pashigian, 2003). Opportunity costs can be measured indirectly by the willingness to pay someone else for undertaking a shopping trip to a store ( $x_{42}$; Kotzab and Teller, 2005a). According to Teller et al. (2006) we consider there is an effect of shopping logistics to the cost of shopping which results in the following hypotheses:

$\mathrm{H}_{2 \mathrm{a}}$ : The better store-related shopper logistics attributes $\left(\xi_{1}\right)$ are perceived the lower the estimated costs of store-based shopping $\left(\xi_{4}\right)$ are. 
$\mathrm{H}_{2 \mathrm{~b}}$ : The longer the shopper logistics-related time $\left(\xi_{2}\right)$ the higher the estimated cost of storebased shopping $\left(\xi_{4}\right)$ are.

Based on the notions of Eastlick and Feinberg (1999) we propose that the convenience of shopping and the cost of shopping as overall evaluations of the undertaken shopper logistics tasks affect patronage behaviour in terms of share of visits to a store (Bell et al., 1998). The resultant hypotheses are:

$\mathrm{H}_{3 \mathrm{a}}$ : The better the convenience of store-based shopping $\left(\xi_{3}\right)$ is perceived the higher the share of visits $\left(\eta_{1}\right)$.

$\mathrm{H}_{3 \mathrm{~b}}$ : The lower the costs of store-based shopping $\left(\xi_{4}\right)$ are perceived the higher the share of visits $\left(\eta_{1}\right)$.

This set of hypothesis spans our conceptual model which, apart from the direct effects, proposes indirect relationships between the included factors as shown in Figure 1.

Figure 1 near here

By following the S-O-R theory, the constructs of evaluating store-based shopping from a convenience and cost point of view mediate the effect between the shopper logistics constructs $\left(\xi_{1}, \xi_{2}\right)$ and the share of visits $\left(\eta_{1}\right)$. These resulting indirect effects can be justified as follows. Bell et al. (1998) and Hand et al. (2009) see the logistics effort as drivers of store format choice. Further, Ingene (1984) regards perceived time constraints of consumer as a main determinant of store patronage. Consequently, we propose both store-related shopper logistics attributes and shopper logistics-related time as determinants for the share of visits. 
Granzin et al. (1997) used shopper logistics-related personal and behavioural characteristics of consumers as a base for identifying and consequently differentiating between different consumer segments. Such variables can thus be seen as influencing the relevance of shopper logistics and as moderators on the proposed effects operationalised in our six hypotheses. Beside others personal characteristics age $\left(\mu_{1}\right)$ can determine the ability to carry out shopper logistics (Keillor et al., 1996; Teller and Gittenberger, 2011). The relevance of the shopping logistics as part of the shopping experience is also strongly dependent on the shopping orientation whereas a hedonic shopping orientation $\left(\mu_{2}\right)$ decreases the perception of shopping as a burden (e.g., Babin et al., 1994). Behavioural characteristics indicating the extend of the shopper logistics tasks are shopping frequency $\left(\mu_{3}\right)$, average spending per trip $\left(\mu_{4}\right)$, then number of persons within the household supplied by each shopping trip $\left(\mu_{5}\right)$ and the use of transport means $\left(\mu_{6}\right)$ (Granzin et al., 1997). Finally the format of the preferred store $\left(\mu_{7}\right)$ determines the extent of shopper logistics due to heterogeneous format specific characteristics like e.g. the location, floor space, depth and with of product range and in-store services (Solgaard and Hansen, 2003).

This leads to the last hypotheses where we propose moderating effects as follows:

$H_{m}:$ The ability $\left(\mu_{1}\right)$, the willingness $\left(\mu_{2}\right)$ and extent of carrying out shopper logistics task $\left(\mu_{3^{-}}\right.$ $\mu_{7}$ ) significantly moderates the relevance of shopper logistics as proposed in $H_{1 a b}, H_{2 a b}$ and $H_{3 a b}$.

The next section discusses the methodology used to empirically test this model.

\section{Methodology}

Empirical research design 
Our empirical study focused on grocery consumers, as that sector of the retail market is the most significant as identified above, and we surveyed those respondents who are mainly responsible for the procurement of groceries within their households. They can be seen as experts in the field of shopper logistics as they are confronted with the management and execution of logistics tasks on a regular basis when buying groceries. Thus, they have the most in-depth knowledge about shopper logistics within their household.

We defined all households within the capital city ( $\sim 2$ million inhabitants) of a central European country as our population and drew a quota sample of 603 consumers using age, household size and household income as quota controls. These variables were chosen since they distinguish between the different extents of logistics tasks to be undertaken in households (Rhee and Bell, 2002). As mentioned, age differentiates between the different abilities of respondents to carry out shopper logistics (e.g. Keillor et al., 1996; Meneely et al., 2009). Household size takes into account differences in the amount of products to be bought. Household income considers the different opportunities but also the potential to outsource shopping logistics to retailers by being able to pay for delivery fees.

Professional interviewers confronted respondents with a standardised questionnaire. Regarding the survey structure we first asked respondents to focus exclusively on the most frequently visited grocery store in order to increase the concreteness of the phenomenon for them. Thereafter we asked them questions on shopper logistics-related to visiting these patronised stores.

The retail market in the selected city can be described as typical for central and western European urban retail environments: highly concentrated, declining number of small independent grocery shops and a high outlet density. The demographic characterisation of 
respondents is shown in Table 1. There were no significant differences regarding incomes of households, number of persons living in the household and age compared to the overall population $\left(X^{2}\right.$-test; $\left.p>.05\right)$.

\section{Table 1 near here}

\section{Scales and analysis}

The conceptual model includes both reflective and formative scales (for a detailed discussion regarding the differences, see Jarvis et al., 2003). In terms of the reflective constructs $\xi_{1}, \xi_{3}$, and $\eta_{1}$, the indicators representing manifestations of the constructs were taken from literature (see Appendix; Granzin and Bahn, 1989; Teller et al., 2006). They were pre-tested according to suggestions by Churchill (1979). In terms of the formative constructs, the characteristics of the constructs $\xi_{2}$ and $\xi_{4}$ are defined by the items. The completeness of indicators of each factor is supported by Ingene (1984) in terms of $\xi_{2}$ and by Bell et al. (1989) in terms of $\xi_{4}$.

Since most of the constructs in our model are of latent nature we applied variance-based structural equation modelling using the partial-least-square (PLS) approach to analyse the proposed effects (Chin, 1998; Tenenhaus et al., 2005), and the software SmartPLS (Ringle et al., 2005). The PLS approach conveys a number of advantages in terms of the required sample size, level of measurement and multinormality compared to a co-variance based structural equation modelling approach. Most importantly, the PLS approach allows to include both formative and reflective constructs (Fornell and Bookstein, 1982; Chin and Newsted, 1999).

Finally, we measured the significance of interaction effects of all proposed moderating variables on an interval scale level $\left(\mu_{1}-\mu_{5}\right)$ based on the two-step approach as described by 
Chin et al. (2003). For all variables on a binary scale level $\left(\mu_{6}\right.$ and $\left.\mu_{7}\right)$ we applied multigroups comparisons as proposed by Keil et al. (2000).

\section{Results}

Local fit

We first evaluated the measurement or outer models (i.e. the sets of constructs with the observable items standing behind them. Subsequently we investigated the proposed effects between the latent constructs within the structural or inner models.

All $t$-values of the factor loadings prove to be highly significant $(p<0.001)$ and all loadings exceed the suggested size of 0.7 (Hulland, 1999). The internal consistency is also considered satisfactory for all factors with Cronbach Alphas exceeding 0.7 (Nunnally, 1978) and the composite reliability of all factors greater than 0.7 ( $\rho$, Fornell and Larcker, 1981).

The degree of the convergent validity is acceptable with average variances extracted (AVE) in the range of 0.5 or higher (Bagozzi and $\mathrm{Yi}, 1988$ ). With regard to the constructs' discriminant validity, the AVE is larger than the highest squared intercorrelation with every other factor in the measurement models; i.e. the Fornell-Larcker-Ratio (FLR) is less than $<1.0$ (Fornell and Larcker, 1981).

\section{Hypothesis testing}

By following Chin (1998) we evaluated the structural model by using the coefficients of determination $\left(r^{2}\right)$, the size, signs and significance of the single path coefficients $\left(\gamma_{\mathrm{n}}\right)$ and the effect sizes $\left(f^{2}\right)$. The results are shown in Table 2 . 
The store-related shopper logistics attributes $\left(\xi_{1}\right)$ have a highly significant and very strong positive effect on convenience of store-based shopping $\left(\xi_{3}\right)$. This finding therefore clearly supports hypothesis $\mathrm{H}_{1 \mathrm{a}}$. Shopper logistics-related time $\left(\xi_{2}\right)$ also has a significant negative impact on convenience whereas the effect can be regarded as being quite weak. Nevertheless, this finding supports $\mathrm{H}_{1 \mathrm{~b}}$.

The time construct shows a highly significant and medium sized effect on the costs of storebased shopping $\left(\xi_{4}\right)$ which leads to the support of $\mathrm{H}_{2 \mathrm{~b}}$. However, the effect between the storerelated shopper logistics attributes $\left(\xi_{1}\right)$ and the costs of shopping in $\left(\xi_{4}\right)$ stores is extremely low and insignificant. This finding clearly does not support $\mathrm{H}_{2 \mathrm{a}}$.

Finally, there is a no significant impact of the convenience of store-based shopping $\left(\xi_{3}\right)$ and the shopping costs $\left(\xi_{4}\right)$ and share of visits $\left(\eta_{1}\right)$. Consequently, both overall evaluations of the store-based shopping process do not contribute to the explanation of the behavioural consequences substantially. Consequently $\mathrm{H}_{3 \mathrm{a}}$ and $\mathrm{H}_{3 \mathrm{~b}}$ are clearly not supported.

By taking into consideration the indirect effects of our shopper logistics constructs on the share of visits $\left(\eta_{1}\right)$, we find that neither store-related shopper logistics attributes $\left(\gamma_{31} *_{13}+\gamma_{41} * \gamma_{14},-.018 ; t\right.$-value, .771; $p$-value, .441) nor shopper logistics-related time $\left(\gamma_{32} * \gamma_{13}+\gamma_{42} * \gamma_{14},-.001 ; t\right.$-value, .094; $p$-value, .925) show a significant impact.

The coefficients of determination indicate that a considerable degree of variance in the construct convenience of store-based shopping $\left(\xi_{3}, r^{2}, .305\right)$ is explained. However, the explanatory power of those constructs proposed to affect the costs of store-based shopping $\left(\xi_{4}, r^{2}, .076\right)$ and the share of visits $\left(\eta_{1}, r^{2}, .010\right)$ is quite low. 
The measurement of interaction effects revealed the following significant results as depicted in Table 3). Age and shopping frequency moderates the effect $\gamma_{31}$ significantly; for both variables the moderating effect result into a higher impact between store-related shopper logistics attributes $\left(\xi_{1}\right)$ and the convenience of store-based shopping $\left(\xi_{3}\right)$. Average spending per trip moderates effect $\gamma_{42}$ positively and significantly. Consequently, higher spending results in a higher impact of shopper logistics-related time $\left(\xi_{2}\right)$ on the cost of store-based shopping $\left(\xi_{4}\right)$. The impact $\left(\gamma_{13}\right)$ of the convenience of store-based shopping $\left(\xi_{3}\right)$ on the share of visits $\left(\eta_{1}\right)$ is affected by the hedonic shopping orientation and the type of patronised format. The more respondents have a hedonic shopping orientation the higher the impact of convenience on the share of visits. Further, this impact is significantly highest for patrons of hypermarkets compared to those of supermarkets and discount stores. Despite the significance of identified moderating effects we see that the effect size measured by $f^{2}$-value is around .02 and thus to be considered as weak. Nevertheless, we conclude that hypothesis $\mathrm{H}_{\mathrm{m}}$ can be confirmed for the variables age $\left(\mu_{1}\right)$, hedonic shopping orientation $\left(\mu_{2}\right)$, shopping frequency $\left(\mu_{3}\right)$, average spending per trip $\left(\mu_{4}\right)$ and the store format preference $\left(\mu_{7}\right)$. The number persons for whom the respondent shops $\left(\mu_{5}\right)$ and the use of a means of transport $\left(\mu_{6}\right)$ show no significant impact on any of the six effects and consequently the hypothesis is rejected there.

\section{Table 3 near here}

\section{Discussion}

The findings clearly show the relevance of shopper logistics for the convenience of storebased shopping in the grocery sector confirming previous suppositions of Ingene (1984), Gert and Yan (2004) and Granzin et al. (2005). In particular, the store-related shopper logistics 
attributes linked to transportation, picking and packing activities of consumers can be considered as relevant for store-based shoppers. In other words, the convenience attached to a shopping experience can be an influencer to facilitate logistics endeavours by making the store easy to access, clearly laying out the stores, arranging products and displaying prices clearly, and making enough cash tills available when needed. This finding calls for making the shopping process simpler for consumers in terms of logistics activities (Baker et al., 2002). This is particularly true for consumers of a higher age and those who shop at grocery stores more often. We thus identify the relevance of shopper logistics in a grocery retail setting for elderly and frequent shoppers and thereby confirm work by Keillor et al. (1996), Meneely et al. (2009), Reutterer and Teller (2009) and Teller and Gittenberger (2011).

Further, and in line with Ingene (1984), the other determinant of the convenience of storebased shopping is time. The perception of time in-store can be influenced by streamlining and optimising shopper logistics as suggested above and by influencing perceptions. That can be achieved for example by minimising obvious waiting times at counters or cash tills which are perceived as non-value adding activities by shoppers (Bennett, 1998).

Inline with Bell et al. (1998) and Ingene (1984), shopping time has an impact on the perceived cost of shopping. The impact is higher for those consumers who spend more per trip which ultimately indicates the size of shopping baskets. By confirming Granzin et al. (1997) we conclude that the shopper logistics is more relevant for those consumers who are exposed to the logistics task more by picking, packing and moving more products per trip than others. However, we cannot confirm Ingene's (1984) notions in terms of the impact of store-related shopper logistics attributes on perceived cost of shopping. 
A major finding is that across all respondents the perception and evaluation of shopper logistics does not result in behavioural consequences measured by the share of visits, which confirms findings from Teller et al. (2006). Further, neither (in-)convenience nor the cost of store-based shopping can be seen as a major driver for store patronage. Nevertheless, we see a moderating effect of the hedonic shopping orientation and the store format patronage behaviour. For more hedonic oriented shoppers convenience has a higher impact on the patronage behaviour than for less hedonic shoppers. This extends the findings from Babin et al. (1994) in terms of grocery retailing. They see convenience more important for utilitarian shoppers compared to hedonic ones. Further, the results of the group of hypermarket patrons indicate that store-related shopper logistics attributes have a significant total effect $\left(\gamma_{31} * \gamma_{13}+\gamma_{41} * \gamma_{14}, .124 ; t\right.$-value, 1.955; $p$-value, .05) and convenience a significant direct effect $\left(\gamma_{13}, .209 ; t\right.$-value, $2.000 ; p$-value, .05) on the share of visits. Thus, shopper logistics is of relevance for patrons of large retail formats like hypermarkets compared to supermarket and discount stores.

We conclude that shopper logistics is relevant for consumers of store-based grocery retail formats; it particularly influences the convenience dimension of the shopping experience. The relevance of shopper logistics is influenced by both the ability and the willingness to carry out and extent of the shopper logistics task. This ultimately suggests that shopper logistics is perceived and evaluated and consequently impacts of different consumer groups distinctively and thus is a relevant criterion to segment consumer markets as suggested by Granzin et al. (1997).

\section{Limitations and further research}

Like every empirical study there are some limitations in this work that motivates further research. The urban retail market investigated can be seen as representative for many others 
in developed European cities. Nevertheless, we neglected markets with other spatial and infrastructural characteristics. We therefore suggest replicating our study in more rural areas and countries/cities with a less developed infrastructure.

This paper focused solely on the relevance of shopper logistics for consumers of store-based grocery retail formats. As many grocery retailers offer home delivery services that feature all products, including perishable items, consumer decision making regarding these services should be investigated.

Lastly, our results demonstrate the high relevance of shopper logistics on the convenience of store-based grocery shopping. Further research could focus explicitly on the individual elements of attributes related to convenience considered in our model, i.e. items behind the construct, to improve, for example, store accessibility, store layout, arrangement of categories and products in-store, display of prices in-store, and store check-out procedures.

\section{References}

Alba, J., Lynch, J., Weitz, B., Janiszewski, C., Lutz, R., Sawyer, A., Wood, S., 1997. Interactive home shopping: Consumer, retailer, and manufacturer incentives to participate in electronic market places. Journal of Marketing 61 (3), 38-53.

Bagozzi, R.P., Yi, Y., 1988. On the evaluation of structural equation models. Journal of the Academy of Marketing Science 16 (1), 74-94.

Babin, B. J., Darden, W. R. Griffin, M., 1994. Work and/or fun: Measuring hedonic and utilitarian shopping value. Journal of Consumer Research, 20 (4), 644-656.

Baker, J., Parasuraman, A., Grewal, D., Voss, G.B., 2002. The influence of multiple store environment cues on perceived merchandise value and patronage intentions. Journal of Marketing 66 (2), 120-141.

Bearden, W.O., 1977. Determinant attributes of store patronage - downtown versus outlying shopping centers. Journal of Retailing 53 (2), 15-22.

Beatson, A., Coote, L. V. Rudd, J. M., 2006. Determining consumer satisfaction and commitment through self-service technology and personal service usage. Journal of Marketing Management 22 (2), 853-882. 
Bell, D.R., Ho, T-H., Tang, C.S., 1998. Determining where to shop. Fixed and variable costs of shopping. Journal of Marketing Research 35 (3), 352-369.

Bennett, R. 1998. Customer recall of promotional displays at supermarket checkouts: arousal, memory and waiting in queues. International Review of Retail, Distribution and Consumer Research; 8 (4), 383-398.

Chin, W.W., 1998. The partial least squares approach to structural equation modelling. In: Marcoulides, G.A. (Ed.), Modern methods for business research. Lawrence Erlbaum Associates, Mahwah (NJ), pp. 295-336.

Chin, W.W., Newsted, P.R., 1999. Structural equation modelling: Analysis with small samples using partial least squares. In: Hoyle, R.H. (Ed.), Statistical strategies for small sample research. Sage, Thousand Oaks (CA), pp. 295-336.

Churchill, G.A., 1979. A paradigm for developing better measures of marketing constructs. Journal of Marketing Research 16 (1), 64-73.

CSCMP, 2011. Definitions. Retrieved from http://www.cscmp.org, viewed 22 May 2011.

Dennis, C., Merrilees, B., Jayawardhena, C., Wright, L.T., 2009. E-consumer behaviour. European Journal of Marketing 43 (9/10), 1121-1139.

Doherty, N.F., Ellis-Chadwick, F., 2009. Exploring the drivers, scope and perceived success of e-commerce strategies in the UK retail sector. European Journal of Marketing 43 (9/10), $1246-1262$.

Donovan, R.J., Rossiter, J.R., 1982. Store atmosphere: An environmental psychology approach. Journal of Retailing 58 (9/10), 34-57.

Eastlick, M.A., Feinberg, R.A., 1999. Shopping motives for mail catalog shopping. Journal of Business Research 45 (3), 281-290.

Finn, A., Louviere, J.J., 1996. Shopping center image, consideration, and choice: Anchor Store Contribution. Journal of Business Research 35 (3), 241-251.

Fornell, C., Bookstein, F.L., 1982. Two structural equation models: LISREL and PLS applied to consumer exit-voice theory. Journal of Marketing Research 19 (4), 440-452.

Fornell, C., Larcker, D.F., 1981. Evaluating structural equation models with unobservable variables and measurement error. Journal of Marketing Research 18 (1), 39-40.

Fotheringham, S.A., 1988. Consumer store choice and choice set definition. Marketing Science 7 (3), 299-310.

Gehrt, K.C., Yan, R.N., 2004. Situational, consumer, and retailer factors affecting Internet, catalog, and store shopping. International Journal of Retail and Distribution Management 32 (1), 5-18.

Grace, D., O'Cass, A., 2005. An examination of the antecedents of repatronage intentions across different retail store formats. Journal of Retailing and Consumer Services 12 (4), 227243. 
Granzin, K.L., Bahn, K.D., 1989. Consumer logistics: Conceptualization, pertinent issues and a proposed program for research. Journal of the Academy of Marketing Science 17 (1), 91101.

Granzin, K.L., Painter, J.J., Bahn, K.D., 2005. An empirical test of households' participation in the distribution supply chain process. Journal of Marketing Channels 12 (4), 67-89.

Granzin, K.L., Painter, J.J., Valentin, E.K., 1997. Consumer logistics as a basis for segmenting retail markets: An exploratory inquiry. Journal of Retailing and Consumer Services 4 (2), 99-107.

Hand, C., Riley, F.D., Harris, P., Singh, J., Rettie, R., 2009. Online grocery shopping: The influence of situational factors. European Journal of Marketing 43 (9/10), 1205-1219.

Hansen, T., 2008. Consumer values, the theory of planned behaviour and online grocery shopping. International Journal of Consumer Studies 32 (2), 128-137.

Hernandez, B., Jiminez, J., Martin, M.J., 2009. Adoption vs. acceptance of e-commerce: Two different decisions. European Journal of Marketing 43 (9/10), 1232-1245.

Huff, D.L., 1964. Defining and estimating a trading area. Journal of Marketing 28 (3), 34-38.

Hulland, J., 1999. Use of partial least squares (PLS) in strategic management research: A review of four recent. Strategic Management Journal 20 (2), 195-204.

Ingene, C.A., 1984. Productivity and functional shifting in spatial retailing: Private and social perspectives. Journal of Retailing and Consumer Services 60 (3), 15-26.

Jarvis, C.B., Mackenzie, S.B., Podsakoff, P.M., Mick, D.G., Bearden, W.O., 2003. A critical review of construct indicators and measurement model misspecification in marketing and consumer research. Journal of Consumer Research 30 (2), 199-218.

Keil, M., Tan, B.C.Y., Wei, K., Saarinen, T., Tuunainen, V., Wassenaar, A., 2000. A crosscultural study on escalation of commitment behavior in software projects. MIS Quarterly 24 (6), 299-325.

Keillor, B. D. Parker R. S., Erffmeyer R. C. 1996. The evaluative criteria of the elderly in a retail experience: product-related vs. store-related factors. Journal of Marketing Management $6(2), 61-71$.

Kotzab, H., Teller, C., 2005a. To pay or not to pay, that is the question. Conceptual model and empirical results on consumers' view on home delivery. In: Kornum, N., Mogens, B. (Eds.), Grocery e-commerce. Consumer behaviour and business strategies. Edward Elgar Publishing: Cheltenham (UK), Northampton (MA, USA), pp. 36-57.

Kotzab, H., Teller, C., 2005b. Development and empirical test of a grocery retail instore logistics model. British Food Journal 107 (8), 594-605.

KPMG, 2011. BRC-KPMG Retail Sales Monitor January 2011.

http://www.kpmg.com/UK/en/IssuesAndInsights/ArticlesPublications/NewsReleases/Pages/B RC-KPMGRetailSalesMonitorJanuary2011.aspx, viewed 22 May 2011. 
Mazursky, D., Jacoby, J., 1986. Exploring the development of store images. Journal of Retailing 62 (2), 145-165.

Meneely, L., Strugnell, C., Burns, A. 2009. Elderly consumers and their food store experiences. Journal of Retailing and Consumer Services, 16 (11), 458-465.

Mehrabian, A., Russel, J.A., 1974. An Approach to Environmental Psychology. MIT-Press, Cambridge (MA).

Mintel, 2009. Online grocery retailing. Market Intelligence. September 2009. Mintel, London.

Mintel, 2010. European Retail Handbook 2009/2010. Mintel, London.

Murphy, A., 2003. (Re)Solving space and time: Fulfilment issues in online grocery retailing. Environment and Planning A 35 (7), 1173-1200.

Nunnally, J.C., 1978. Psychometric Theory. McGraw-Hill, New York.

Pan, Y., Zinkhan, G.M., 2006. Determinants of retail patronage: A meta-analytical perspective. Journal of Retailing 82 (3), 229-243.

Pashigian, P.B., 2003. Firm responses to income inequality and the cost of time. Review of Industrial Organization 22 (4), 253-273.

Reilly, W.J., 1931. The Law of Retail Gravitation. New York.

Reinartz, W.J., Kumar, V., 1999. Store-, market-, and consumer-characteristics: The drivers of store performance. Marketing Letters 10 (1), 5-23.

Reutterer, T., Teller, C., 2009. Store format choice and shopping trip types. International Journal of Retail and Distribution Management 37 (8), 695-710.

Rhee, H., Bell, D.R., 2002. The inter-store mobility of supermarket shoppers. Journal of Retailing 78 (4), 225-237.

Ring, L.J., Tigert, D.J., 2001. Viewpoint: The decline and fall of Internet grocery retailers. International Journal of Retail and Distribution Management 29 (6/7), 266-273.

Ringle, C.M., Wende, S., Will, A., 2005. SmartPLS 2.0 (beta). http://www.smartpls.de, viewed 22 May 2011. University of Hamburg, Hamburg.

Ruiz, J.P., Chebat, J.C., Hansen, P., 2004. Another trip to the mall: A segmentation study of customers based on their activities. Journal of Retailing and Consumer Services 11 (6), 333350 .

Sherman, E., Mathur, A., Smith, R.B., 1997. Store environment and consumer purchase behavior: Mediating role of consumer emotions. Psychology and Marketing 14 (4), 361-378.

Solgaard, H.S., Hansen, T. (2003). A hierarchical Bayes model of choice between supermarket formats. Journal of Retailing and Consumer Services, 10 (3), 169-80. 
Tang, C.S., Bell, D.R., Ho, T.-H., 2001. Store choice and shopping behavior: How Price format works. California Management Review 43 (2), 56-74.

Teller, C., Gittenberger, E., 2011. Patronage behaviour of elderly supermarket shoppers antecedents and unobserved heterogeneity. International Review of Retail, Distribution and Consumer Research, 21 (5), in print.

Teller, C., Kotzab, H., Grant, D.B., 2006. The consumer direct services revolution in grocery retailing: An exploratory investigation. Managing Service Quality 16 (1), 78-96.

Tenenhaus, M., Vinzi, V., Chatelin, Y.M., Lauro, C., 2005. PLS path modelling. Computational Statistics and Data Analysis 48 (1), 159-205.

Ward, M.R., 2001. Will online shopping compete more with traditional retailing or catalog shopping?" Netnomics 3 (2), 103-117.

Xing, Y., Grant, D.B., 2006. Developing a framework for measuring physical distribution service quality of multi-channel and "pure-player" internet retailers. International Journal of Retail and Distribution Management 34 (4/5), 278-289.

Xing, Y., Grant, D.B., McKinnon, A.C., Fernie, J., 2010. Physical distribution service quality in online retailing. International Journal of Physical Distribution and Logistics Management $40(5), 415-432$. 


\section{Appendix: Scales and local fit measures}

\begin{tabular}{|c|c|c|c|}
\hline \multirow{2}{*}{$\begin{array}{l}\text { Factor } \\
\text { Indicator }\end{array}$} & \multicolumn{3}{|c|}{ Measures/indices } \\
\hline & $\mu(\sigma)$ & $\alpha / \rho$ & AVE/FLR \\
\hline \multicolumn{4}{|l|}{$\xi_{1}:$ Store-related shopper logistics attributes } \\
\hline$x_{11}$ : Difficult to access $\leftrightarrow$ easy to access ${ }^{\dagger}$ (a) & $1.1(1.6)$ & \multirow{6}{*}{$.765 / .836$} & \multirow{6}{*}{$.560 / .615$} \\
\hline$x_{12}:$ Confusing layout $\leftrightarrow$ clear layout $^{\dagger(\mathrm{b})}$ & $1.0(1.7)$ & & \\
\hline$x_{13}$ : Products difficult to find $\leftrightarrow$ easy to find ${ }^{\dagger(\mathrm{c})}$ & $1.0(1.8)$ & & \\
\hline$x_{14}$ : Prices difficult to recognise $\leftrightarrow$ easy to recognise ${ }^{\dagger(\mathrm{d})}$ & $-1.8(1.8)$ & & \\
\hline$x_{15}:$ Unsupportive personnel $\leftrightarrow$ supportive personnel $\mathrm{l}^{\dagger(\mathrm{e})}$ & $1.2(1.4)$ & & \\
\hline$x_{16}:$ Not enough cash desks available $\leftrightarrow$ enough available ${ }^{\dagger(\mathrm{f})}$ & $1.6(1.4)$ & & \\
\hline \multicolumn{4}{|l|}{$\xi_{2}:$ Shopper logistics-related time } \\
\hline$x_{21}:$ Access time ${ }^{\dagger \dagger(\mathrm{g})}$ & $6.4(4.6)$ & \multirow[b]{2}{*}{ n.a. } & \multirow[b]{2}{*}{ n.a. } \\
\hline$x_{22}:$ Retention time $\mathrm{e}^{\dagger \dagger(\mathrm{h})}$ & $21.3(12.0)$ & & \\
\hline \multicolumn{4}{|l|}{$\xi_{3}:$ Convenience of store-based shopping } \\
\hline$x_{31}$ : Inconvenient $\leftrightarrow$ convenient $^{\dagger(\mathrm{i})}$ & $1.6(1.6)$ & \multirow{4}{*}{$.670 / .797$} & \multirow{4}{*}{$.597 / .569$} \\
\hline$x_{32}$ : Exhausting $\leftrightarrow$ not exhausting ${ }^{\dagger(\mathrm{j})}$ & $1.0(1.9)$ & & \\
\hline$x_{33}$ : Time intensive $\leftrightarrow$ not time intensive $\mathrm{e}^{\dagger(\mathrm{k})}$ & $0.8(1.8)$ & & \\
\hline$x_{34}:$ Stressful $\leftrightarrow$ relaxing $^{\dagger(1)}$ & $0.8(1.7)$ & & \\
\hline \multicolumn{4}{|l|}{$\xi_{4}:$ Costs of store-based shopping } \\
\hline$x_{41}:$ Estimated costs ${ }^{\dagger \dagger \dagger(\mathrm{m})}$ & $2.9(5.2)$ & \multirow[b]{2}{*}{ n.a. } & \multirow[b]{2}{*}{ n.a. } \\
\hline $\begin{array}{l}x_{42} \text { : Willingness to pay for someone else undertaking the } \\
\text { shopping trip }\end{array}$ & $3.6(4.4)$ & & \\
\hline \multicolumn{4}{|l|}{$\eta_{1}:$ Share of visits } \\
\hline $\begin{array}{l}y_{11} \text { : Share of visits to this store compared to all visits to grocery } \\
\text { stores }\end{array}$ & $69.7(16.7)$ & n.a. & n.a. \\
\hline \multicolumn{4}{|c|}{$\begin{array}{l}\text { Caption: } \dagger \text {, bipolar } 7 \text { point rating scale }(-3 \leftrightarrow+3) \text { including a neutral middle category }(0) \text {; } \dagger \dagger \text {, metric scale, } \\
\text { minutes; } \dagger \dagger \dagger \text {, metric scale, Euro; } \dagger \dagger \dagger \text {, per cent, metric scale; } \mu \text {, mean value; } \sigma \text {, standard deviation; } \alpha \text {, } \\
\text { Cronbach's Alpha; } \rho \text {, composite reliability; AVE, average variance extracted; FLR, Fornell-Larcker-ratio }\end{array}$} \\
\hline \multicolumn{4}{|c|}{$\begin{array}{l}\text { Notions: Cutoff values for measurement validity: } \alpha>.7 ; \rho>.6 ; \text { AVE }>.5 ; \text { FLR }<1 \text { (Fornell and Larcker, 1981; } \\
\text { Baggozzi and Yi, 1988); since different units of measurement were used the values were converted into } z- \\
\text { scores for modelling purposes }\end{array}$} \\
\hline \multicolumn{4}{|c|}{$\begin{array}{l}\text { Sources: (a), Reinartz and Kumar, 1999; (b), Tang et al., 2001; (c) (d), Eastlick and Feinberg, 1999; (e), Baker } \\
\text { et al., 2002; (f), Tang et al., 2001; (g), Rhee and Bell, 2002; (h), Baker et al., 2002; (i), Eastlick and Feinberg, } \\
\text { 1999; (j), Teller } \text { et al., 2006; (k), Eastlick and Feinberg, 1999; (l), Baker et al., 2002; (m), Bell et al., 1998; } \\
\text { Pashigian, 2003; Kotzab and Teller, 2005; (n), Kotzab and Teller, 2005; (o), Teller et al., 2006; }\end{array}$} \\
\hline
\end{tabular}


Figure 1: Conceptual model

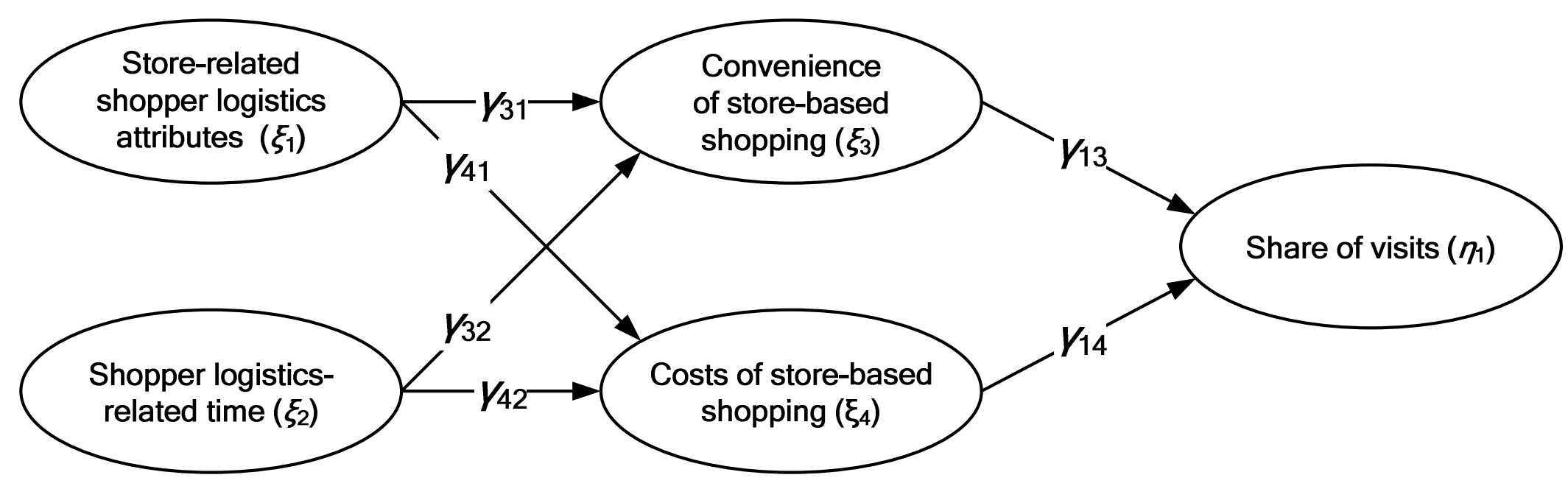


Table 1: Demographic characterisation of respondents

\begin{tabular}{ll}
\hline Demographic variables & Characterisation \\
\hline Gender & Female, 67.5\% \\
Age (years) & $\mu($ mean value), 41.6; $\sigma$ (standard deviation), 15.9 \\
Household income (Euro per month) & $\mu, 2,223.7 ; \sigma, 1,382.5$ \\
Share of expenditures for grocery as a percentage of & $\mu, 23.4 \% ; \sigma, 14.2 \%$ \\
the household income & \\
Number of persons in households (incl. respondents) & $\mu, 2.0 ; \sigma, 1.1$ \\
Education (Top 3) & A-Level/pre university qualification, 42.2\% \\
& University degree, $18.8 \%$ \\
& Secondary school diploma, $17.6 \%$ \\
Profession (Top 3) & White collar worker, 41.9\% \\
& Student/Trainee, $18.4 \%$ \\
& Senior citizen, $14.3 \%$ \\
\hline
\end{tabular}


Table 2: Structural effects

\begin{tabular}{lcccc}
\hline $\begin{array}{l}\text { Hypothesis, } \\
\text { effect }\end{array}$ & $\begin{array}{c}\text { Path } \\
\text { coefficient }\end{array}$ & $f^{2}$-values & $t$-values & $p$-values \\
\hline $\mathrm{H}_{1 \mathrm{a}}, \gamma_{31}$ & .545 & .334 & 16.472 & $<.001$ \\
$\mathrm{H}_{1 \mathrm{~b}}, \gamma_{32}$ & -.146 & .010 & 3.039 & .002 \\
\hline $\mathrm{H}_{2 \mathrm{a}}, \gamma_{41}$ & .039 & .022 & 1.058 & .290 \\
$\mathrm{H}_{2 \mathrm{~b}}, \gamma_{42}$ & .270 & .080 & 6.151 & $<.001$ \\
\hline $\mathrm{H}_{3 \mathrm{a}}, \gamma_{13}$ & -.032 & .001 & .761 & .447 \\
$\mathrm{H}_{3 \mathrm{~b}}, \gamma_{14}$ & -.013 & .001 & .268 & .789 \\
\hline
\end{tabular}

Notions: Sample size $\mathrm{n}=603$; $t$-values calculated by applying a bootstrapping procedure with 1,000 sub-samples (Chin, 1998) 


\section{Table 3: Moderating effects}

\begin{tabular}{|c|c|c|c|c|c|c|c|c|c|c|}
\hline \multicolumn{2}{|c|}{ Moderators } & \multirow[t]{2}{*}{$\mu_{1}:$ Age $^{\mathrm{I}}$} & \multirow{2}{*}{$\begin{array}{l}\mu_{2}: \text { Hedonic } \\
\text { shopping } \\
\text { orientation }\end{array}$} & \multirow{2}{*}{$\begin{array}{c}\mu_{3}: \text { Shopping } \\
\text { frequency per } \\
\text { month }^{\mathrm{I}}\end{array}$} & \multirow{2}{*}{$\begin{array}{l}\mu_{4}: \text { Average } \\
\text { spending per } \\
\text { trip }^{I}\end{array}$} & \multirow{2}{*}{$\begin{array}{l}\mu_{5}: \text { Shopping } \\
\text { for x persons } \\
\text { in household }^{\mathrm{I}}\end{array}$} & \multirow{2}{*}{$\begin{array}{c}\mu_{6}: \text { Use of } \\
\text { transport } \\
\text { means }{ }^{I I} \\
\Delta_{\text {onf, trans }} \\
\end{array}$} & \multicolumn{3}{|c|}{$\begin{array}{l}\mu_{7}: \text { Patronised store format (supermarket, } \\
\text { hypermarket, discount store) }{ }^{\mathrm{II}}\end{array}$} \\
\hline Effects & & & & & & & & $\Delta_{s m, h m}$ & $\Delta_{s m, d s}$ & $\Delta_{h m, d s}$ \\
\hline \multirow[t]{3}{*}{$\gamma_{31}$} & $\beta_{\xi_{1}}$ & $.525^{* * *}$ & $.515^{* * *}$ & $.532^{* * *}$ & $.535^{* * *}$ & $.531^{* * *}$ & $t_{(601)}, .701^{\mathrm{ns}}$ & $t_{(445)}, .578^{\mathrm{ns}}$ & $t_{(464)}, 1.685^{\dagger}$ & $t_{(291)}, .760^{\mathrm{ns}}$ \\
\hline & $\beta_{\mu_{\mathrm{n}}}$ & $.045^{\dagger}$ & $.105^{* *}$ & $.047^{\dagger}$ & $-.066^{\dagger}$ & $-.015^{\mathrm{ns}}$ & & & & \\
\hline & $\beta_{\mu_{\mathrm{n}}, \xi_{1}}$ & $.134^{* * *}$ & $.032^{\mathrm{ns}}$ & $.082^{*}$ & $-.003^{\mathrm{ns}}$ & $-.056^{\mathrm{ns}}$ & & & & \\
\hline \multirow[t]{3}{*}{$\gamma_{41}$} & $\beta_{\xi_{1}}$ & $.074^{\dagger}$ & $.062^{\mathrm{ns}}$ & $.060^{\mathrm{ns}}$ & $-.055^{\mathrm{ns}}$ & $.054^{\mathrm{ns}}$ & $t_{(601)},-.763^{\mathrm{ns}}$ & $t_{(445)},-.079^{\mathrm{ns}}$ & $t_{(464)}, .668^{\mathrm{ns}}$ & $t_{(291)}, .487^{\mathrm{ns}}$ \\
\hline & $\beta_{\mu_{\mathrm{n}}}$ & $-.070^{\dagger}$ & $-.023^{\mathrm{ns}}$ & $-.115^{* *}$ & $-.142^{* *}$ & $.122^{* *}$ & & & & \\
\hline & $\beta_{\mu_{\mathrm{n}}, \xi_{1}}$ & $-.019^{\mathrm{ns}}$ & $-.050^{\mathrm{ns}}$ & $-.003^{\mathrm{ns}}$ & $.007^{\mathrm{ns}}$ & $-.010^{\mathrm{ns}}$ & & & & \\
\hline \multirow[t]{3}{*}{$\gamma_{32}$} & $\beta_{\xi_{2}}$ & $.029^{\mathrm{ns}}$ & $.245^{* * *}$ & $-.109^{* *}$ & $-.099^{\dagger}$ & $-.099^{*}$ & $t_{(601)}, .286^{\mathrm{ns}}$ & $t_{(445)},-.409^{\mathrm{ns}}$ & $t_{(464)}, .050^{\mathrm{ns}}$ & $t_{(291)}, .277^{\mathrm{ns}}$ \\
\hline & $\beta_{\mu_{\mathrm{n}}}$ & $.021^{\mathrm{ns}}$ & $-.130^{* *}$ & $.013^{\mathrm{ns}}$ & $-.018^{\mathrm{ns}}$ & $.020^{\mathrm{ns}}$ & & & & \\
\hline & $\beta_{\mu_{\mathrm{n}}, \xi_{2}}$ & $-.038^{\mathrm{ns}}$ & $-.045^{\mathrm{ns}}$ & $-.063^{\text {ns }}$ & $-.025^{\mathrm{ns}}$ & $-.009^{\mathrm{ns}}$ & & & & \\
\hline \multirow[t]{3}{*}{$\gamma_{42}$} & $\beta_{\xi_{2}}$ & $.278^{* * *}$ & $.301^{* * *}$ & $.266^{* * *}$ & $.246^{* * *}$ & $.264^{* * * *}$ & $t_{(601)}, 1.737^{\dagger}$ & $t_{(445)}, 1.364^{\mathrm{ns}}$ & $t_{(464)}, .788^{\mathrm{ns}}$ & $t_{(291)},-.356^{\mathrm{ns}}$ \\
\hline & $\beta_{\mu_{\mathrm{n}}}$ & $-.075^{\dagger}$ & $-.061^{\mathrm{ns}}$ & $-.059^{\mathrm{ns}}$ & $.077^{\dagger}$ & $.099^{*}$ & & & & \\
\hline & $\beta_{\mu_{\mathrm{n}}, \xi_{2}}$ & $-.076^{\dagger}$ & $-.068^{\dagger}$ & $.023^{\mathrm{ns}}$ & $.080^{*}$ & $-.009^{\text {ns }}$ & & & & \\
\hline \multirow[t]{3}{*}{$\gamma_{13}$} & $\beta_{\xi_{3}}$ & $-.034^{\mathrm{ns}}$ & $-.015^{\mathrm{ns}}$ & $-.031^{\mathrm{ns}}$ & $-.028^{\mathrm{ns}}$ & $-.033^{\text {ns }}$ & $t_{(601)}, .899^{\mathrm{ns}}$ & $t_{(445)},-2.552 *$ & $t_{(464)}, .768^{\mathrm{ns}}$ & $t_{(291)}, 2.663^{* * *}$ \\
\hline & $\beta_{\mu_{\mathrm{n}}}$ & $.002^{\mathrm{ns}}$ & $-.059^{\mathrm{ns}}$ & $.101^{* *}$ & $.171^{* * *}$ & $-.015^{\mathrm{ns}}$ & & & & \\
\hline & $\beta_{\mu_{n}, \xi_{3}}$ & $.009^{\mathrm{ns}}$ & $.096^{*}$ & $-.045^{\mathrm{ns}}$ & $.008^{\mathrm{ns}}$ & $-.015^{\mathrm{ns}}$ & & & & \\
\hline \multirow[t]{3}{*}{$\gamma_{14}$} & $\beta_{\xi_{4}}$ & $-.003^{\mathrm{ns}}$ & $-.006^{\mathrm{ns}}$ & $-.006^{* *}$ & $.097^{\mathrm{ns}}$ & $-.005^{\mathrm{ns}}$ & $t_{(601)},-.332^{\mathrm{ns}}$ & $t_{(445)},-1.543^{\mathrm{ns}}$ & $t_{(464)},-.323^{\mathrm{ns}}$ & $t_{(291)}, .806^{\mathrm{ns}}$ \\
\hline & $\beta_{\mu_{\mathrm{n}}}$ & $.005^{\mathrm{ns}}$ & $-.055^{\mathrm{ns}}$ & $.097^{\mathrm{ns}}$ & $-.006^{* *}$ & $-.014^{\mathrm{ns}}$ & & & & \\
\hline & $\beta_{\mu_{\mathrm{n}}, \xi_{4}}$ & $.046^{\mathrm{ns}}$ & $.040^{\mathrm{ns}}$ & $-.013^{\text {ns }}$ & $-.013^{\text {ns }}$ & $-.029^{\mathrm{ns}}$ & & & & \\
\hline \multicolumn{11}{|c|}{ 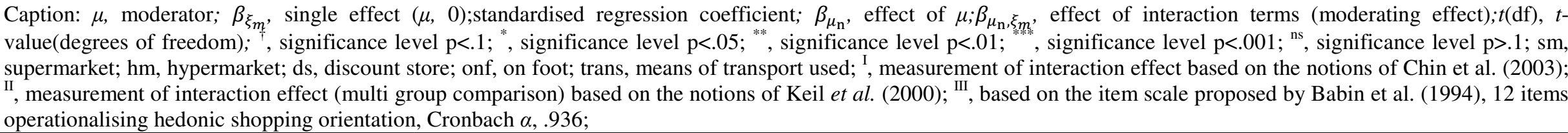 } \\
\hline
\end{tabular}

